\title{
Többdimenziós kulturális értékłeremtés a Veszprém-Balaton2023 Európa Kulturális Fővárosa projekt tükrében
}

\author{
Lőrincz Katalin ${ }^{a}$ - Raffay-Danyi Ágnes ${ }^{a}$ - Mara Cerquetti ${ }^{b}$ \\ aPannon Egyetem, 'University of Macerata
}

\begin{abstract}
A TANULMÁNY CÉLJA
A tanulmány célja a kulturális értékteremtés jellemzőinek bemutatása a Veszprém-Balaton2023 Európa Kulturális Fővárosa program (továbbiakban Veszprém-Balaton2023 EKF program) tükrében. A vizsgálatot a többdimenziós értékteremtés öt pillére alapján végeztük Veszprémben és a Balaton térségben müködö kulturális és turisztikai szervezetek körében. Jelen kutatás a következő kérdésekre fókuszál: 1) hogyan müködik közre jelenleg a kulturális szektor a város és a Balaton térség fenntartható fejlesztésében; 2) melyek a veszprémi kulturális szakpolitika és menedzsment legfőbb gyengeségei, fejlesztendő területei; 3) melyek azok az EKF-től várt hatások, melyek hosszú távon ösztönözhetik a helyiek kultúrához való kapcsolódását, illetve kulturális fogyasztását? A tanulmány a kulturális és turisztikai szektorban megjelenő közösségi részvétel és a hálózatosítás szerepére fókuszál, amely segítségével megvalósulhat a térség hosszú távú kulturális, társadalmi és gazdasági fejlődése.
\end{abstract}

\begin{abstract}
ALKALMAZOTT MÓDSZERTAN
Az értékteremtéssel kapcsolatos nemzetközi és hazai szakirodalom áttekintése alapján megalkottuk a kutatás elméleti kereteit: a többdimenziós értékteremtés öt pillérének vizsgálatát végeztük az esettanulmány (Veszprém-Balaton2023 EKF program) megközelítés mentén. A kutatást 2019 szeptemberében és októberében bonyolítottuk le Veszprém és a Balaton térségben strukturált interjúk, valamint stratégiai dokumentumok elemzésének segítségével. Az interjúalanyok kiválasztása során törekedtünk a kultúra minél szélesebb területének lefedésére és a turizmus kiterjedt ernyőfogalma alatt (láthatatlan, nem konvencionális, mindennapi térpályáktól eltérő mobilitás) tárgyalt folyamatok (Michalkó - Ilyés 2020) vizsgálatára. Ebből adódóan a strukturált interjúk során kilenc kulturális intézmény (kulturális központ, könyvtár, színház, múzeum, mủvészeti galéria), továbbá a veszprémi és a térségi turisztikai desztináció menedzsment szervezetek képviselőinek véleményét elemeztük.
\end{abstract}

\section{LEGFONTOSABB EREDMÉNYEK}

A kutatási eredmények a részvétel, a bevonódás és a hálózatosodás különböző szintjeit mutatják be. Olyan releváns innovációkat javasolnak, melyek a kulturális szféra hosszú távú fenntartható fejlesztése érdekében megvalósíthatók.

\section{GYAKORLATI JAVASLATOK}

Az eredmények a kulturális alapú városfejlesztésben érdekelt, valamint a kulturális kínálatot, programokat priorizáló hazai települések számára tartalmaznak menedzsmentre vonatkozó javaslatokat. Az eredmények alapján a Veszprém-Balaton térségben a kulturális kínálat jelenlegi irányítása fejlesztésre szorul; kiemelten átgondolandó az értékteremtési mechanizmusok megújitása.

Kulcsszavak: Európa Kulturális Fővárosa, többdimenziós értékteremtés kulturális szervezetek, életminöség, fenntartható fejlesztés

Köszönetnyilvánitás: Jelen kutatás az Európai Unió, Magyarország és az Európai Szociális Alap társfinanszírozása által biztosított forrásból az EFOP-3.6.2-16-2017-00017 azonosítójú „Fenntartható, intelligens és befogadó regionális és városi modellek" címủ projekt keretében jött létre.

DOI: 10.15170/MM.2021.55.02.02 


\section{BEVEZETÉS INTRODUCTION}

Sacco et al. (2018, 6-7) szerint társadalmi-szakmai szempontok alapján az értékteremtés három uralkodó rendszerét lehet elkülöníteni. Az első az úgynevezett védnökségen alapuló „Kultúra 1.0”, mely az iparosodás előtti gazdaságra jellemző, ahol a kultúra csak nagyon kevesek számára elérhető A „Kultúra 2.0” szinten a kultúra közönségének száma jelentősen növekszik, és közérdek a közönség fejlesztése. Bár a kulturális és kreatív tevékenységek gazdasági értékteremtése már megkezdődik és nyereségessé válik, a kultúra továbbra is a gazdaság egy csekély jelentőségü szektora. Végül a „Kultúra 3.0” szintet az értékteremtés szerkezeti átalakulása által ösztönzött innovációk jellemzik. A szerzők úgy vélik, hogy ekkor , , termelők csoportjának ,robbanása” jelentösen megnehezíti a kulturális , termelök” és fogyasztók elkülönitését”, így teremtve „egy rétegzett, mindenre kiterjedö szerkezeti kapcsolathálót a gazdaság és a társadalom valamennyi szektora között".

Ebben a rendszerben a közönség tevékeny résztvevő, ugyanakkor eltérően a korunkra jellemző jelenségtől - ahol a tartalom-elóállító egyben fogyasztó is -, itt a közönség részvételének nem nélkülözhető eleme a piac közvetítő szerepe. Az új megközelítésben a szerzők az EU országokat hat csoportba sorolják be, összemérve az országok teljesítményét az innovációban és a kultúra gyakorlati alkalmazásában. A rangsorban Magyarország az utolsó előtti kategóriában szerepel Ciprussal, Görögországgal, Olaszországgal és Portugáliával együtt. Ezt a csoportot az átlagos innovációs, valamint a kultúra alacsony szintủ gyakorlati alkalmazása jellemzi.

A kutatás a Veszprém-Balaton2023 EKF program esetére fókuszálva azt vizsgálja, hogy Veszprém és a Balaton régió kulturális létesítményei szembesülnek-e, s ha igen, hogyan a jelenlegi kulturális kínálatuk innovációjának, közönségük bővítésének és az aktív részvétel növelésének szükségességével. Az elemzés a kulturális létesítmények és szervezetek helyi lakosság életminőségéhez való hozzájárulását, valamint a kulturális kínálat, a kulturális tevékenységek szerepét vizsgálja a fenntarthatóság társadalmi-gazdasági jellemzője szempontjából.

A kutatás két feltételezésen alapul: egyrészt a kulturális létesítményeknek hozzá kell járulniuk az életminőséghez (Kovács és tsai 2006), a helyi szereplőknek (például helyi lakossági civil szervezetek, a turisztikai szektor) használniuk kell azokat.
Másrészt, a fenntartható turisztikai fejlesztések előmozdítása a kulturális és turisztikai szféra létesítményeinek magas fokú együttmüködését igényli (Csapó - Matesz 2007).

A primer kutatás a következő kérdések megválaszolását tủzte ki célul:

1) Hogyan müködik közre jelenleg a kulturális szektor a Veszprém-Balaton térség fenntartható fejlesztésében?

2) Melyek a veszprémi kulturális szakpolitika és menedzsment legfőbb gyengeségei, fejlesztendő területei,

3) Melyek azok az EKF-től várt innovációk, melyek hosszú távon ösztönözhetik a helyiek kultúrához való kapcsolódását, bevonódását, illetve kulturális fogyasztását.

Külön vizsgáltuk a helyi közösségek, a helyi lakosság bekapcsolódásának módját (milyen módon vonják be a veszprémi és a balatoni kulturális létesítmények a helyi közösségeket?) és az együttmüködés szintjét (hogyan müködnek együtt ezek a létesítmények más kulturális és turisztikai szervezetekkel?), annak érdekében, hogy meghatározhassuk a jelenlegi szemléletmód erősségeit és gyengeségeit. Munkánkban kitérünk a Veszprém-Balaton2023 EKF programmal kapcsolatos szükségletekre és innovációs lehetőségekre is.

\section{ELMÉLETI HÁTTÉR THEORETICAL BACKGROUND}

\section{A kultúra többdimenziós hatásának vizsgálata \\ Analysis of the multidimensional impacts of culture}

Az elmúlt 15 évben a „kulturális érték” és a „,kultúra értéke" kifejezések az egyén és a társadalom szintjén egyaránt a nyilvános politikai viták divatos frázisává váltak. Egyre növekszik az érdeklődés a kultúra hatásai iránt, és nem csupán gazdasági vagy társadalmi szempontból, hanem az életminőség, az egészség és a jól-lét (úgymint mentális egészség, idősek, társadalmi periférián élők, tanulási nehézségekkel küzdők és rehabilitáció) vonatkozásában is (Bollo 2013, Scott 2013, Tuck, Dickinson 2014, Brown 2019, Pavluska és tsai 2019).

A kulturális szakpolitika és -menedzsment szemszögéből vizsgálva a jelen kutatás eredményei rávilágítanak annak szükségességére, hogy mérni és értékelni szükséges a kulturális tevékenységek valódi kapacitását. Nehézség, hogy a kulturális tevékenységek direkt és/vagy indirekt módon 
megfogható (például. foglalkoztatás, bérek, üzleti fejlesztés, stb.) és megfoghatatlan (például. kulturális főváros, társadalmi kohézió, életminőség, stb.) hatásának mérésére vonatkozóan nincs adekvát módszer (Whelan 2015). Továbbá még mindig "nehéz ok-okozati kapcsolatot kimutatni a kivitelezett akciók, lépések, projektek és az elért társadalmi haszon között" (Viganò, Lombardo 2018, 333).

A kulturális intézményekre fókuszálva legalább két releváns témával érdemes foglalkozni: az értékteremtéssel és az értékteremtés mérésével. Egy szervezet kultúráját és szokásait a közös értékteremtés által kell megújítani, a kulturális fejlesztési folyamat valamennyi fázisába bevonva az érintetteket (Spence et al. 2013). A szolgáltatás-központú megközelítés kulcseleme a közös értékteremtés (co-creation) (Williams et al. 2020), amelyet a változó fogyasztói elvárások is igazolnak. Egyrészt a fogyasztók láthatóan nagyobb hangsúlyt fektetnek a fizikai és mentális értelemben is egészséges, tartalmas életvitelre, beleértve a családi közös élményteremtést (Péter és tsai 2020); másrészt a látogatókat kiszolgáló létesítmények programkínálatában is igénylik a térségi szolgáltatók közös értékteremtését, vagyis a több szolgáltató és szereplő által létrehozott termékeket, szolgáltatásokat (Kaszás és tsai 2014).

A Bollwerk (2015) által javasolt modell alkalmazásával, az elköteleződés négy szintjét azonosíthatjuk, melyek fokozatosan alakítják a közönséget tömegből közösséggé. Az elköteleződés szintjei a következők: a nyilvánosság (az információ disszeminációja a nagyközönség számára); a részvétel (a közönség aktív bevonása a projektekbe), a közremüködés (melynek során a felhasználóknak beleszólásuk van a magas szintű célok meghatározásába és fejlesztésébe, illetve a tervezésbe), valamint a közös értékteremtés (melyben a felhasználók egyenrangú partnerek a projektek tervezésében és megvalósításában). Ezen elméleti és módszertani perspektíva fejlesztése során a kultúra hatásairól szóló tudományos viták eltolódnak a közönségfejlesztés felől a közösségek felhatalmazása és bevonása irányába. Összegezve elmondható, hogy a közös értékteremtés nem csupán a fogyasztót foglalja magában (Boorsma 2006) - a passzív közönségtöl az ,aktív játékosig" -, hanem egy adott kulturális létesítmény tevékenységei iránt elkötelezett vagy azok által befolyásolt különféle csoportokat is: a felhasználóktól a helyi közösségen át az alkalmazottakig.

A közösségek szélesebb rétegeinek a bevonása az 1990-es évektől vált hangsúlyosabbá az Európa Kulturális Fővárosa programokban. A korábbi gyakorlattal szemben a cím odaítélésénél nem a már bizonyítottan európai értékrenddel bíró városok kerültek előtérbe, hanem azok a települések, melyek az “európaivá válás” folyamatát élték (European Parliament 2014). Glasgow, a komoly gazdasági-társadalmi problémákkal küzdő hanyatló iparváros (1990-ben az első EKF cím birtokosa) a kulturális alapú városfejlesztés irányába történő elmozdulás sikeres példájának tekinthető (Sassatelli 2008). Hasonlóan kulcselemnek tartja a közösségek bevonását Lamour és Durand (2019), akik az EKF program átalakulásának egyik jelentős fázisát az EKF célközönségének a korábbi elit körön túli kiszélesítésére megfogalmazódó igényben és akaratban látják.

Annak érdekében, hogy megértsük a kulturális intézmények hosszú távú hozzájárulását a közös értékteremtéshez (mint például az életminőség, a fenntartható turizmus fejlesztése), egy többszintü keretrendszer szükséges (Cerquetti 2017), mely definiálja a befogadókat (a megszólítandó résztvevők kategóriáit és alkategóriáit), mérlegeli a feladatokat (az egyes kategóriák számára elérendő célokat) és mérhetö indikátorokat alkalmaz (az értékteremtés értékelésének mérése az egyes kategóriákban).

Magyarországon a téma kapcsán már születtek marketinghez is köthető eredmények (Kelemen-Erdős és Mitev 2019). Ercsey (2019) az észlelt érték és a kulturális szolgáltatások vásárlása és fogyasztása közötti kapcsolatot tárta fel, megállapítva, hogy a kulturális szolgáltatás értékében azonosítható a funkcionális, az emocionális és a társadalmi dimenzió.

\section{ANYAG ÉS MÓDSZER MATERIAL AND METHOD}

A primer kutatás azt vizsgálta, hogy Veszprém és a Balaton régió hogyan birkózik meg az érintettek és érdekeltek összekapcsolásának, a közös értékteremtésnek - illetve értékteremtés mérésének - kérdéseivel. A strukturált interjúk során arra kerestük a választ, hogy miként szólítják meg e szervezetek a különböző érdekelteket; hogyan zajlik a közös értékteremtés, valamint mérik-e ezt a folyamatot. A kutatás kiemelten kezelte a Veszprém-Balaton EKF 2023 programból származó lehetőségek feltárását is. Az érdekeltek négy kategóriáját vizsgáltuk: a kulturális szolgáltatások fogyasztóit, a kulturális intézmények alkalmazottait, a helyi közösségeket, valamint a kulturális és turisztikai szektor szervezeteit.

A közös kulturális értékteremtés és a kulturális intézmények méréseire vonatkozó eredmények alapján (Crossick \& Kuszynska 2016, Carlucci, 
2017, Cerquetti, 2017) - figyelembe véve a többdimenziós keret szükségességét, valamint támaszkodva a kutatási hipotézisre - az értékteremtés 5 pillérjét határoztuk meg (1. ábra). Ennek kapcsán a strukturált interjú kérdések az alábbi dimenziókat vizsgálták:

1) A kulturális intézmények hozzájárulása a tudásépitéshez (adottságok): úgymint nyitvatartási idő; müsorok/színdarabok; kulturális tér laboratóriumok oktatási tevékenységkonferenciák, időszakos kiállítások számára; helyszíni és online szolgáltatások;

2) Vonzerő és fogyasztói elégedettség (teljesítmény): a látogatók/felhasználók/közönség száma, változásuk iránya; a célközönség összetétele (lakóhely és kor); a különböző célközönségek vonzásának stratégiái és az ezzel kapcsolatos tevékenységek; látogató/ felhasználó/vevői elégedettség mérése;
3) Közösségi részvétel és bevonás: a helyi iskolákkal/szervezetekkel/csoportokkal fennálló partnerség és a számukra szervezett programok; outdoor tevékenységek; önkéntesek; közösségi és önkéntes elégedettségi mérések;

4) Foglalkoztatás, munkavállalói jól-lét és tanulás: alkalmazottak, szerződés típusok, foglalkoztatás hossza; karrier lehetőségek; munkahelyi tréningek; alkalmazottak elégedettségének mérése;

5) Hálózatosodás a kulturális és turisztikai szektorban: részvétel a hálózatokban, a kulturális és turisztikai ágazat szervezetei közötti partnerségek; bevonás a helyi politikába és várostervezésbe.

\section{1. ábra: A kulturális szervezetek többdimenziós értékteremtésének öt pillére}

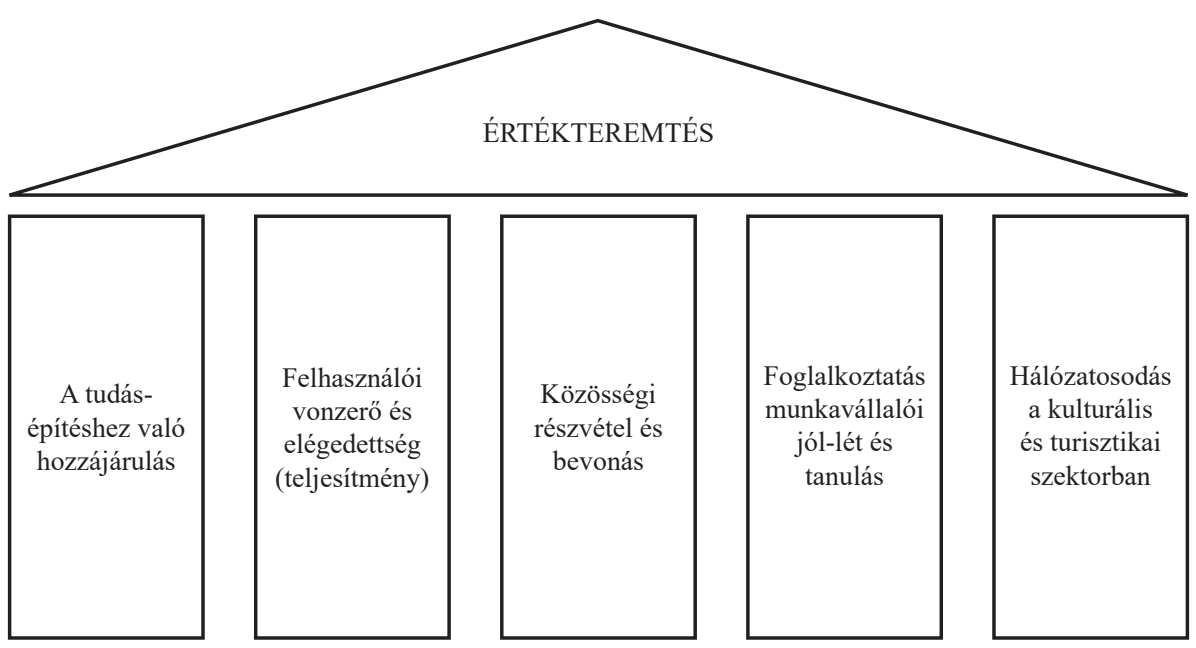

Forrás: saját szerkesztés

A terepkutatást 2019 szeptemberében és októberében végeztük, kilenc kulturális intézmény körében (kulturális központ, könyvtár, színház, múzeum, művészeti galéria) Veszprémben és a Balaton régióban, Keszthelyen. Ezen felül két turisztikai desztináció menedzsment (TDM) szervezet vezetőjét is megkérdeztük a kritikus területekről, amelyek az életminőség és a turisztikai fejlesztések közötti egyensúlyhoz elengedhetetlenek. A kutatás során az EKF programba bevont projekt menedzserrel is készítettünk interjút az EKF projekt előkészítési folyamatáról, a főbb nehézségekről és kihívásokról, valamint a már érzékelhető változásokról.

A strukturált interjúk zárt és nyitott kérdéseket egyaránt tartalmaztak. Az interjúkat rögzítettük, majd átírtuk és visszaküldtük az interjú alanyoknak egy végső egyeztetésre, mielőtt az elemezésre sor került. A kapott válaszokat az intézmények nevesítésével mutatjuk be, csak a több esetben is elhangzó 
hasonló vélemények kerülnek név nélkül, általánosítva ismertetésre. A tanulmányba bevont szervezeteket a müködés, kereslet és kínálat alapján mértük fel. Végezetül az esettanulmány megközelítéssel összhangban (Yin 2018), stratégiai dokumentumokat, jelentéseket és weboldalakat tanulmányoztunk.

\section{EREDMÉNYEK RESULTS}

Veszprém Magyarország egyik legrégebbi városa, hosszú történelmi múlttal, sajátos tradíciókkal, erős helyi identitástudattal és nemzetközileg is elismert programokkal büszkélkedhet (Jászberényi 2020). A Veszprém-Balaton2023 EKF projekt kulcsszava a "Beyond - Túllépni"(a hagyományos módszereken, korlátainkon, a város határain) illetve elsődleges célja az új célközönségek elérése. Az EKF pályázatban bemutatott projekt az alábbi vízión alapul: "versenyképes lakóhely, minőségi turisztikai gazdaság, erösebb bázis a kreatív ipar számára, intelligens örökségvédelem; a kultúra, mint a közösségépités eszköze (erősödö szomszédsági kohézió és a közösségek kooperációja); közönségfejlesztés és müvészeti oktatás" (Veszprém Candidate City 2023 European Capital of Culture, 2018,10).

\section{Az értékteremtés öt pillérének vizsgálata \\ Analysis of the five pillars of value creation}

A tudás gyarapitásához való hozzájárulás kontextusban a kutatási eredmények azt mutatják, hogy növekszik a kulturális létesítmények hozzájárulása az életminőséghez és a fenntartható turisztikai fejlesztéshez. Veszprém és a Balaton régió kulturális létesítményei rendszeresen kínálnak széleskörü kulturális szolgáltatásokat, rendezvényeket, eseményeket. Ugyan számos épület renoválást igényel, az infrastruktúra és az adottságok adekvátak a fö tevékenységekhez, és helyet tudnak biztosítani egyéb kulturális tevékenységek számára is. A Petőfi Színház minden évadban tart elöadásokat a segítségre szoruló nézőknek (feliratozással és jelnyelvi tolmácsolással a siketek, illetve narrációval a látássérültek számára). Az Agóra szintén odafigyel a fogyatékkal élőkre: “akadálymentes az épület, néhány rendezvényen jelnyelvi tolmács is van, Braille irás néhány teremben, és egy kerekesszékes klubnak is helyet adunk".
A kultúra hozzáférhetősége a nyitva tartási időben vagy az információáramlásban, hatékony és naprakész kommunikációban is mérhető. Aggodalomra ad okot a múzeumok és múvészeti galériák nyitva tartása, hiszen vasárnaponként zárva tartanak (pl. a Szaléziánum a téli időszakban, Laczkó Dezső Múzeum és a Müvészetek Háza néhány időszakos kiállítása). További gyengeséget jelentenek az online szolgáltatások. Néhány weboldal csak magyarul nyújt információt, míg más oldalak csupán részben vannak lefordítva angolra. Jelen pillanatban ezek a létesítmények csupán csekély jelenléttel és aktivitással bírnak a social media felületeken, főként rendezvényekről és kiállításokról posztolnak. Véleményünk szerint munkaköri-munkaszervezési lépésekkel ez a helyzet, ha nem is könnyen, de orvosolható.

A kulturális intézmények vonzerejét és a fogyasztók elégedettségét kiemelten kezeli a Veszprém-Balaton2023 EKF program. A régióban a kulturális létesítményeket elsősorban Veszprémből és Veszprém megyéből érkező helyi lakosság veszi igénybe. A gyermekeket és családokat megszólító Kabóca Bábszínház kivételével a veszprémi színházak által szervezett koncertek, előadások, műsorok és egyéb események főként a 45 év felettieket célozzák meg. Az Agóra Veszprém Kulturális Központ látogatóinak nagyjából 40 százaléka 65 év feletti (46 nyugdíjas klubnak adunk otthont). A múzeumok évi 25-30 ezer látogatót vonzanak, míg a Mủvészetek Háza 20 ezernél valamivel kevesebb látogatót: “számos ingyenes rendezvényen van, igy nehéz megmondani a látogatók számát”. A látogatók főként Magyarországról érkeznek (a Balatoni Múzeumban 70 százalékban), és a létesítmények közönségvonzásra irányuló stratégiái, tevékenységei elsősorban az iskolásokat és a tanárokat célozzák meg. A Balatoni Múzeum és a Laczkó Dezső Múzeum a közeli iskolákba is ellátogat, hogy felkeltse a célcsoport figyelmét. A Szaléziánum látogatói az ország egész területéről érkeznek, de a rendezvények és a könyvbemutatók elsősorban a veszprémieknek szólnak.

Sajnálatos tény, hogy a közönség összetételére vonatkozó adatgyüjtés és adatelemzés rendszertelen. Általánosságban elmondható, hogy a vásárlói elégedettséget csak szórványosan mérik, föként az időszakos kiállításokon és az európai uniós pályázatok kapcsán: “néha mértünk elégedettséget, de ez sosem volt szisztematikus. "

A közösségi részvétel és bevonás tekintetében Veszprémben és a Balaton régióban valamennyi kulturális létesítmény szoros kapcsolatot ápol a helyi és környékbeli iskolákkal. Néhány esetben (Agóra Veszprém Kulturális Központ és Eötvös 
Károly Megyei Könyvtár) az általános- illetve középiskolákkal, valamint a környezö falvakkal partnerségi együttmüködés is létrejött.

A foglalkoztatás, alkalmazotti jól-lét és alkalmazottak tanulása kapcsán a kutatás eltérő jellemzőket tárt fel. A vizsgált kulturális létesítmények főként közintézmények, melyeket a város, a megye és a kormány támogat; a Szaléziánum pedig egyházi intézmény. Az alkalmazottak számát tekintve a skála két végpontját jelenti a Hangvilla (4 fö) és a Petőfi Színház (102 fö). A kulturális szektorban nem azonosíthatunk be pénzügyi motivációt, illetve kevés lehetőség nyílik magasabb pozícióba kerülni. Bár a munkavállalók alapvetően elkötelezettek a tevékenységük iránt, a kulturális szervezetek többségében nem nyújtanak az alkalmazottaknak tanulási lehetőséget, valamint az alkalmazotti elégedettséget sem mérik. A fluktuáció intézményenként változó, de pozitív példaként az Agóra szolgál: "1973-ban nyitott a Müvelödési Központ, és vannak, akik a 80-as, 90-es évek óta dolgoznak már itt."

A hálózatosodás mértéke a kulturális és turisztikai szektoron belül viszonylag alacsony szinten áll. Veszprémben és a Balaton régióban csak néhány kulturális létesítmény része valamilyen szakmai vagy tudományos ágazati hálózatnak. Az Eötvös Károly Megyei Könyvtár a Magyar Könyvtárosok Egyesületének, a Balatoni Múzeum a Magyar Múzeumi Egyesületnek, a Laczkó Dezsỏ Múzeum és a Balatoni Múzeum a vidéki múzeumok hálózatának tagja, a Kabóca Bábszínház pedig a kisvárosok a fesztiválok szervezéséért nemzetközi hálózat tagja. Ezen kívül a Múvészete Háza hazai és nemzetközi szinten is együttmüködik más múzeumokkal és galériákkal, valamint "két kolléga egy korábbi EKF városba, Linzbe is ellátogatott tapasztalatszerzés céljából". Helyi szinten az intézmények közötti együttmúködés a turizmus népszerüsítésére és a különleges események szervezésére korlátozódik; többségében tagjai a Veszprémi Turisztikai Egyesületnek is.

\section{VÁRAKOZÁSOK ÉS LEHETŐ- SÉGEK A VESZPRÉM-BALATON 2023 EKF PROJEKT KAPCSÁN EXPECTATIONS AND OPPOR- TUNITIES IN RELATION TO THE VESZPRÉM-BALATON 2023 ECOC PROJECT}

A jelen kutatásban vizsgált kulturális létesítményt nagy elvárásaik vannak az EKF projekt kapcsán. A fö remények a következők: (müemlék) épületük felújitása annak érdekében, hogy a környékröl még több embert és jobb körülmények között tudjanak befogadni: "nagy szükség lenne légkondícionálásra a könyvtár több részében is"; egy kellemesebb helyszín kialakítása; a fogyatékkal élök számára jobb hozzáférés, valamint modern és interaktív állandó kiállitások létesitése; fiatalabb generációkat megszólító kulturális rendezvények szervezésének képessége.

Az Agóra a körülötte fekvő lakótelepen élök bevonásában bízik. A Laczkó Dezső Múzeum - más múzeumokkal együttműködve - kis falvakban tervez régészeti kutatásokat megvalósítani, és a feltárt leleteket kiállítani a közönség számára. A Hangvilla további helyszíneket kíván bevonni tevékenységeibe, míg a Megyei Könyvtár utcai üvegvitrin "könyvtárakat" szeretne nyitni a város különböző pontjain, és helyszínt biztosítani az EKF különféle rendezvényeihez. A Művészetek Háza a kapcsolatrendszer bővítését várja: külföldi művészeket fogadjon a város, illetve a helyi művészek külföldre jussanak tapasztalatcsere célból. A Kabóca Bábszínház felismerte, hogy a közönségfejlesztés egy "általános kötelesség", mely szükségessé teszi a kulturális marketinggel kapcsolatos workshopok és konferenciák szervezését, valamint az alkalmazottak szakmai képességeinek fejlesztését. A térségi TDM szervezet a látogatói élményszerzés oldaláról fogalmazott meg várakozásokat: "Veszprémben kiemelkedö a kultúra és a kulturális örökség, de fontos lenne ezeket nem unalmasan bemutatni. Jó példa a 12 Fal kiállítás a régi zenei általános iskolában, ahol egy használaton kívüli épületet az innovatív falfestés tett vonzóvá." 


\section{JAVASLATOK RECOMMENDATIONS}

A kutatási eredmények azt mutatják, hogy a rendelkezésre álló használaton kívüli tereket új funkcióval lehetne megtölteni: a régi épületeket inkább karbantartani és felújítani szükséges ahelyett, hogy új építésủ kulturális terekkel helyettesítenék ezeket. A kulturális létesítmények próbálnak új közönségeket elérni, emellett pedig megerősíteni kapcsolatukat a már meglévő törzsközösséggel. Ugyanakkor a kiemelkedő kulturális, társadalmi és gazdasági hatás elérése újabb társadalmi innovációkat is igényel: a kulturális intézményeknek fejleszteniük szükséges a szolgáltatói szemléletet a kulturális kínálatban, amely egyfajta "szoftverként" biztosítja a helyreállított épületek (hardver) zökkenőmentes üzemeltetését. Ez az online marketing és a social media eszközök mellett az angol nyelv használatát, illetve a kulturális intézmények ("turistabarát") hétvégi nyitva tartását jelenti.

Kutatásunk alapján azt a következtetést vontuk le, hogy a közönség elérésére, bevonására új "Kultúra 2.0", vagy akár "Kultúra 3.0" szellemü megközelítés szükséges, mely a marketinget nem pusztán eszköznek, hanem stratégiának tartja (Boorsma 2006). További célkitüzés a fogyasztói, látogatói elégedettség mérése, mely a projektet a fö cél eléréséhez szükséges eszköznek, nem pedig az európai projektekhez kapcsolódó kötelezettségnek tekinti. Veszprém kulturális kínálatát vonzó módon (attrakciómenedzsment, gamifikáció) kívánatos népszerüsíteni és bemutatni.

Helyi, települési szinten a köz- és magánintézmények közötti alacsony szintü kooperációra és koordinációra kell felhívni a figyelmet, különösen a Várban, a város történelmi központjában lévő múzeumok és örökségi helyszínek között. Ebben a kontextusban a Veszprém-Balaton2023 EKF program nagyszerủ lehetőség: a projekt kapcsán alkalom nyílik közvetlenül "az emberekbe invesztálni", összehozva a különböző érdekelteket/érintetteket, összekapcsolva az EKF projektet a régió helyi lakosságával. A szélesebb körủ együttmüködés kétségtelenül több vendéget (helyi lakost, turistát) és turisztikai szolgáltatót is vonzhat a kultúrán keresztül. A változás mindazonáltal folyamatban van: az EKF programért felelős cégangol nyelvi kurzusokat szervez, a város kulturális intézményei számára angol nyelvü weboldalt alakít ki, illetve egy önkéntes platformot nyit a helyi részvétel növelésére.

\section{ÖSSZEGZÉS SUMMARY}

Jelen kutatás a kulturális szektor jelenlegi hozzájárulását vizsgálta Veszprém és a térség helyi lakosságának életminőséghez, valamint a fenntartható fejlődéshez. A tanulmány bemutatta a jelenlegi kulturális kínálat fö kihívásait, valamint az EKF sikeréhez szükséges elvárt innovációkat, melyek hosszú távon közelebb hozhatják a kultúrát az helyi lakosokhoz és a turistákhoz, és szélesítik szerepének, jelentőségének megértését. Munkánkban a többdimenziós értékteremtés öt pillérét vizsgáltuk, melynek kapcsán az alábbi fő következtetéseket vonhatjuk le.

A kutatási eredmények igazolják az EKF kapcsán végzett korábbi kutatásokat, jelezve, hogy fejleszteni szükséges a kulturális kínálat jelenlegi menedzselését (Aquilino et al. 2019). A menedzsment fejlesztésének egyik alapja, hogy átgondoljuk az értékteremtési mechanizmusok működtetésének és megújításának módját. Schiuma s Lerro (2017, 3) nyomán hangsúlyozzuk, hogy elengedhetetlen az üzleti modell-alapú innováció: ,, a müvészeteknek és a kulturális intézményeknek vállalniuk kell a szükséges fejlesztö lépéseket az irányitásban csakúgy, mint müködésük megújitásában".

Az eredmények ugyan nem általánosíthatók, de a kutatásba bevont kulturális szervezetek tapasztalatai alapján levonható néhány következtetés a kulturális alapú területfejlesztésre vonatkozóan. A kutatás egyik limitációja, hogy az interjúk során föképp veszprémi kulturális (és turisztikai) szervezetek képviselői mondták el a véleményüket, a Balaton térséget összesen két interjúalany képviselte. A továbbiakban szükséges az EKF projekthez társult további települések kulturális kínálatát és azok kapcsán az értékteremtés öt pillérét vizsgálni. A tanulmányban bemutatott eredmények túlnyomóan a kulturális intézmények képviselőinek véleményét tükrözik, érdemes lenne tehát a témát a többi stakeholder oldaláról is megközelíteni: a munkavállalói jólét pillért az érintettek oldaláról is vizsgálni, a közösségek részvételét és bevonását a kultúrafogyasztó közönség percepcióinak feltárásával értékelni, valamint a hálózatosodást a turisztikai szolgáltatók szemszögéből is elemezni. 


\section{HIVATKOZÁSOK REFERENCES}

Aquilino, L., Armenski, T., - Wise, N. (2019), Assessing the competitiveness of Matera and the Basilicata Region (Italy) ahead of the 2019 European Capital of Culture. Tourism and Hospitality Research, 19(4), 503-17. DOI: https:// doi.org/10.1177\%2F 1467358418787360

Bollo, A. (2013), Measuring Museum Impacts. Report 3. LEM - The Learning Museum. Retrieved from http://online.ibc.regione.emilia-romagna.it/I/libri/pdf/LEM3rdreport-measuring-museum-impacts.pdf.

Bollwerk, E. (2015), Co-Creation's Role in Digital Public Archaeology. Advances in Archaeological Practice, 3, 223-34. DOI:10.7183/23263768.3.3.223

Boorsma, M. (2006), A strategic logic for arts marketing: integrating customer value and artistic objectives. International Journal of Cultural Policy, 12(1), 73-92. DOI: https://doi. org/10.1080/10286630600613333

Brown, K. (2019), Museums and Local Development. An Introduction to Museums, Sustainability and Well-being. Museum International, 71(3-4), 1-13. DOI:10.1080/13500775.2019.1 702257

Carlucci, D. (2018), Fostering excellence in business model management in arts and cultural organisations: insights from focus group research across Europe. Measuring Business Excellence, 22(1), 14-30. DOI: https://doi. org/10.1108/MBE-12-2017-0094

Cerquetti, M. (2017), "From value assessment to public value creation and measurement in the museum sector. Theoretical approaches and critical issues in a changing world". In: Bridging theories, strategies and practices in valuing cultural heritage. Macerata: eum, 121-47.

Crossick, G., Kaszynska, P. (2016), Understanding the value of arts \& culture. The AHRC Cultural Value Project. Swindon: Arts and Humanities Research Council.

Csapó J. - Matesz K. (2007), A kulturális turizmus jelentősége és szerepe napjaink idegenforgalmában. Földrajzi Értesitö, 56(34), 291-301.

Ercsey I. (2019), Közös az értékteremtés a kulturális szektorban?. Marketing \& Menedzsment, 48(3), 36-46. Elérés forrás https://journals.lib. pte.hu/index.php/mm/article/view/985

European Parliament, \& Council of the European Union (2014), Decision No 445/2014/Eu of the European Parliament and of the Council of 16
April 2014 establishing a Union action for the European Capitals of Culture for the years 2020 to 2033 and repealing Decision No 1622/2006/ $E C$. Retrieved from https://eur-lex.europa.eu/ legal-content/EN/TXT/PDF/?uri=CELEX:32014D0445\&from=EN.

Jászberényi M. (szerk.), A kulturális turizmus sokszínűsége. Budapest, Akadémiai Kiadó. $2020 \mathrm{https}: / /$ doi.org/10.1556/9789634545224.

Kaszás, N., Fehérvölgyi, B., Keller K. (2015), A térségi turizmusfejlesztés lehetőségei a magyar-szlovén határ mentén, avagy merre gurul az 5 Postakocsi? In: Lőrincz I. (szerk.) Quid est veritas? (Jn 18,38) Teóriák, hipotézisek és az igazság viszonya. XVIII. Apáczai-napok Tudományos Konferencia, Györ. Nyugat-magyarországi Egyetem Kiadó, 499-507.

Kelemen-Erdős, A. - Mitev, A. (2019), Holisztikus szolgáltatásélmény - vendég-utazás és kölcsönös értékteremtés dimenziói az art- és romkocsmák példáján. Marketing \& Menedzsment, 50(3-4), 88-101. Elérés forrás https:// journals.lib.pte.hu/index.php/mm/article/ view/888

Kovács B. - Horkay N. - Michalkó G. (2006), A turizmussal összefüggő életminőség-index kidolgozásának alapjai. Turizmus Bulletin, 2, 19-26.

Lamour, C., Durand, F. (2019), European Capitals of Culture across state borders. In: W. Schneider, K. Jacobsen (eds.). Transforming Cities. Paradigms and Potentials of Urban Development Within the "European Capital of Culture. Hildesheim: OLMS, 41-50.

Michalkó G. - Ilyés N. (2020), A nemkonvencionális turisztikai mobi-litás magyarországi sajátosságai, különös tekintettel a turizmusból származó bevételek növelésének lehetőségére. Turizmus Bulletin, 20(Különszám), 6-18. DOI:10.14267/TURBULL.2020v20n4.1

Pavluska V. - Jakopánecz E. - Törőcsik M. (2018), Kultúra. A magyar lakosság kultúrával kapcsolatos beállítódása és követett magatartása generációs szemléletü vizsgálattal. Kézirat. EFOP3.6.1-16-2016-00004, PTE KTK, Pécs

Péter E., Tóth-Kaszás N., Keller K., Birkner Z., Kiss A., Németh K. (2020), Mesés kalandozások: a balatoni családok kikapcsolódási alternatívái. Comitatus: Önkormányzati Szemle, 30(235), 64-71.

Sacco. P. L., Ferilli, G., - Tavano Blessi, G. (2018), "From Culture 1.0 to Culture 3.0: Three Socio-Technical Regimes of Social and Economic Value Creation through Culture, and Their Impact on European Cohesion Policies". 
Sustainability, 10 3923, 1-23. DOI: 10.3390/ su10113923

Sassatelli, M. (2008), European Cultural Space in the European Cities of Culture. European Societies, 10(2), 225-45. DOI: https://doi. org/10.1080/14616690701835311

Schiuma, G., Lerro, A. (2017), The business model prism: Managing and innovating business models of arts and cultural organisations. Journal of Open Innovation: Technology, Market, and Complexity, 3(3). DOI: 10.1186/s40852-0170066-z

Scott, C.A., (ed.), Museums and Public Value. Creating Sustainable Futures. Farnham: Ashgate, 2013

Spence, D., Wareham, T., Bressey, C., Bam-Hutchison, J., Day, A. (2013), The Public as Co-producers: Making the London, Sugar and Slavery Gallery, Museum of London Docklands. In: C. A., Scott, ed., Museums and Public Value. Creating Sustainable Futures. Farnham: Ashgate, 95-109.

Tuck, F., Dickinson, S. (2014), The Economic Impact of Museums in England, prepared by TBR's Creative \& Cultural Team in partnership with Pomegranate LLP and Scott Dickinson \& Partners Ltd. Retrieved from https://www. artscouncil.org.uk/sites/default/files/download-file/Economic_Impact_of_Museums_in England_report.pdf.

Veszprém Candidate City 2023 European Capital of Culture (2018), "Bid Book. Veszprém" Veszprém-Balaton 2023 Ltd.
Viganò, F., Lombardo, G. (2018), L'impatto sociale generato dai musei. L'applicazione della metodologia SROI. In: A. Luigini, C. Panciroli (eds.), Ambienti digitali per l'educazione all'arte e al patrimonio. Milano: FrancoAngeli. 332-50.

Whelan, G. (2015), Understanding the social value and well-being benefits created by museums: A case for social return on investment methodology. Arts \& Health. An International Journal for Research, Policy and Practice, 7(3), Culture, Museums and Wellbeing, 216-230. DOI: 10.1080/17533015.2015.1065574

Williams, M., Biggemann, S., Tóth, Z. (2020), Value creation in art galleries: A service logic analysis. Australasian Marketing Journal, 28 47-56. DOI: https://doi.org/10.1016/j.aus$\mathrm{m},,,,, j .2019 .08 .002$

Yin, R. (2018), Case Study Research and Applications. Design and Methods. $6^{\text {th }}$ edition. Thousand Oaks, CA: Sage. 
Lőrincz Katalin $\mathrm{PhD}$, egyetemi docens lorincz.katalin@gtk.uni-pannon.hu

Raffay-Danyi Ágnes PhD, egyetemi docens raffay.agnes@gtk.uni-pannon.hu

Pannon Egyetem, Gazdaságtudományi Kar

Mara Cerquetti MSc, Associate Professor in Management mara.cerquetti@unimc.it

University of Macerata, Department of Education, Cultural Heritage and Tourism

\section{Multidimensional Cultural Value Creation in Relation to the Veszprém-Balaton2023 European Capital of Culture Project}

\section{THE AIM OF THE PAPER}

The study aims to discuss the characteristics of cultural value creation in relation to the Veszprém-Balaton 2023 European Capital of Culture project. The analysis is based on the five pillars of multidimensional value creation focusing on the cultural organisations operating, along the following research questions: 1) How can the cultural sphere contribute to the sustainable development of the city and the Balaton region?; 2) What are the weaknesses of the cultural policy and management in Veszprém that could be improved?; 3) What are the expected outcomes of the ECoC project that could foster community involvement in culture and cultural consumption? The study focuses on the role of community involvement and networking in the cultural and tourism sectors that could contribute to the long term cultural, social and economic development of the region.

\section{METHODOLOGY}

The framework of the research was established based on a literature review on value creation. The assessment of the five pillars of value creation involved the analysis of strategic documents and key informant interviews. Structured interviews were conducted in September and October 2019, with the involvement of the cultural institutions and tourism organisations of Veszprém and the Balaton region. During the selection of the interviewees a key aspect was to cover a wide range of areas of culture, so the representatives of nine cultural institutions (ranging from culture centre, library, theatre, museum to art gallery), and those of the Veszprém and the regional tourism destination management organisations were interviewed.

\section{MOST IMPORTANT RESULTS}

Research results demonstrate various levels of involvement and networking, and suggest relevant innovations that could be implemented to achieve long term sustainable development.

\section{RECOMMENDATIONS}

The results also contain management suggestions for further settlements joining the cultural programmes. The operation and renewal of the value creating mechanisms need re-thinking.

Keywords: European Capital of Culture, value creation, cultural organisations, quality of life, sustainable development 